\title{
Social Development and Revolution in Iran
}

Forthcoming in Sociology of Development. Volume 8 Issue 2, June 2022.

\author{
Mohammad Ali Kadivar \\ Assistant Professor of Sociology and International Studies \\ Boston College \\ kadivarm@,bc.edu \\ McGuinn Hall 406 \\ Morrissey College of Arts and Sciences \\ 140 Commonwealth Avenue \\ Chestnut Hill, MA 02467
}

I thank Charles Kurzman, Ben Bradlow, Maryam Alemzadeh, Eskandar Sadeghi-Boroujerdi, Xiaohong $\mathrm{Xu}$, and Neil Ketchley for their comments on the earlier drafts of this article. I also thank the editors and the two anonymous reviewers for their constructive feedback.

Keywords: Revolution, War, Development, Welfare, Iran 


\title{
Social Development and Revolution in Iran
}

\begin{abstract}
The scholarship about the consequences of social revolutions contends that social revolutions boost state capacity and strengthen the state's developmental projects. Social justice and addressing the needs of ordinary citizens also were central themes in the discourse of the Iranian revolution and the Islamic Republic that emerged as the post-revolutionary regime with the fall of the monarchy in Iran. In this essay, I assess the performance of the post-revolutionary state in Iran according to different development indicators. Specifically, I compare the record of the post-revolutionary regime with the pre-revolutionary regime. My examination of various indicators relating to health, education, poverty, income inequality, and housing presents more of a mixed result than the overall improvement that previous scholarship anticipated and that the post-revolutionary regime had promised. Furthermore, the evidence points to declines in some important areas of development and welfare provision. Based on this analysis, I propose directions for future research about the developmental outcome of revolutions.
\end{abstract}




\section{Introduction}

The social effects of revolutions have been the subject of scholarly debate within comparative historical sociology (Beck 2017, 2020). Most importantly, Theda Skocpol (1979, 1995), in her analyses of French, Russian, and Chinese Revolutions and the American Civil War, argued that social revolutions and wars could boost the state's capacity, bring social equality, and lead to the formation of social policy. In 1979, the same year that Skocpol's State and Social Revolutions was published, her argument faced a serious challenge with the outbreak of a revolution in Iran that did not align with Skocpol's theoretical model about the major causes of social revolutions. Skocpol had argued that social revolutions occurred in countries that experienced a breakdown of the state resulting from an international crisis and that ideology did not play an important role in such revolutions. The Iranian revolution of 1979 defied both parts of her argument to the extent that Skocpol (1982) wrote an article a few years later contending that her argument did not extend to a case such as Iran. Over the last four decades, Skocpol's theory about the causes of revolutions has been much scrutinized (Burawoy 1989; Mahoney 1999), but her contentions about the consequences of revolutions have not been extensively assessed.

Now, 40 years after the Iranian revolution, we are in a good position to assess revolutionary outcomes in hindsight. Social justice and serving ordinary people were among the major themes in the Iranian revolution and for the Islamic Republic since its inception. Upon his return to Iran on February 1, 1979, Ayatollah Khomeini gave a famous speech Behesht-e Zahra a cemetery in the south of Tehran, to emphasize the illegitimacy of the monarchy. In that speech, Khomeini (1979a) said, "[The shah] has ruined all that we had; he has destroyed our country; instead, he has expanded our graveyards. He has destroyed the country's economy; all our economy is now ruined and is such a complete shamble that if we wish to restore it to its original condition with the people's efforts, it will take long years.” In another famous speech on March 1, 1979, Khomeini (1979b) promised to 
improve the lives of Iranians both in terms of material and spiritual welfare. Furthermore, he promised to provide housing, free electricity, and free water. These promises are still remembered by ordinary Iranians when they reflect on the performances and legacies of the Islamic Republic. Themes of social justice and welfare provision also find a home in the Constitution of the Islamic Republic. The introduction to the Constitution has a section on the economy that indicates that "meeting the human needs for growth and evolution" is the main principle in the organization of the economy. Accordingly, "Islam's economic program is to provide the apt conditions for various human capacities to flourish. As a result, it is upon the Islamic government to provide employment for all and to meet all necessary human needs." Article 3 of the Constitution obliges the government to use its capacities to provide free education and welfare, remove poverty, and all deprivations in nutrition, housing, employment, and health. ${ }^{1}$ Furthermore, since 1989, the Islamic Republic has passed six Five-Year Development Plans (Majles-e Showra-ye Eslami 1989, 1995, 2000, 2005, 2011, 2016) in which promotion of social justice, reduction of poverty and income inequality, health provision, housing provision, expansion of education, and the advancement of economic growth are among the major goals of the development plans. How has the Islamic Republic lived up to these promises and plans four decades after the revolution? Was the Iranian revolution an inclusive social revolution as anticipated by the theories of revolutionary outcomes?

Social development has been the subject of inquiry and debate among scholars of Iranian politics and society, and different studies have examined various policy outcomes in Iran in different periods. About a decade ago, Iran's prominent historian Ervand Abrahamian (2009) argued that the Islamic Republic's achievements in areas of education, health, poverty reduction, subsidies, service provision in rural areas, and welfare provision in general have made the regime resilient and

\footnotetext{
${ }^{1}$ The full text of the constitution including its introduction could be accessed at https://rc.majlis.ir/fa/content/iran constitution
} 
contributed to its survival despite various domestic and international challenges it has faced. The argument proposed by Abrahamian then has been expanded and elaborated by other scholars of development and welfare in Iran. In his recent book $A$ Social Revolution: Politics and the Welfare State in Iran, sociologist Kevan Harris specifically focused on development and welfare before and after the revolution and inquired about the effect of the revolution and war on such outcomes in Iran. Harris deserves credit for asking the question about the social consequences of revolution and war and for bringing Iran to existing debates at the global level about the drivers of welfare and development. The book notes that both before and after the 1979 revolution, Iran had had developmental and welfare states. However, according to the book's argument, the welfare and development projects after the revolution have been more "inclusive" than those before the revolution, which the book characterizes as "exclusive." The book then argues that this inclusive character is due to higher levels of popular mobilization and the more competitive politics from the 1979 revolution onward. As evident from the argument and the title of the book, this contention is, in a way, a variation and extension of Skocpol's argument about the positive effects of social revolutions and wars on development and welfare. A Social Revolution is an important contribution to the studies of welfare and development in Iran and an ambitious attempt to provide an explanation for major transformations in Iran's welfare provision and social development (for another example emphasizing Islamic Republic's policy success see also Ameli 2020). This argument about the effective state performance in the area of social development, however, is challenged by other scholars of Iran's social development. Political economists writing in a recent, edited volume, Economic Welfare and Inequality in Iran: Developments since the Revolution, give more of a mixed picture of the performance of the Islamic Republic in terms of development and welfare. This volume covers a variety of related subjects such as income inequality, the size of the middle class, oil rents, housing costs, gender inequality in the labor market, aging, and sanctions. A major advantage of this volume 
is that it offers well-specified hypotheses, clear definitions, and relevant data from sources such as Iran's censuses, central bank, and world bank. Another analysis of social development by economist Masoud Karshenas (2015) also concludes that the Islamic Republic has underperformed in provision of health and basic education, when compared with Egypt and Turkey. Finally, different studies by Djavad Salehi Isfahani $(2017,2019)$ also point out policy successes after the revolution and several significant policy failures.

In this essay, I argue that the results of revolution and war for social development are, at best, mixed, where we observe improvement for some indicators, continuation for some indicators, and decline for some other important indicators. I support this argument by presenting new data from Iran's censuses and statistical yearbooks. I situate my analyses of the data in dialogue with the literature that has been produced on this topic. My examination of the literature and evidence shows that the consequences of the Iranian revolution present further challenges and complications for Skocpol's theory.

\section{Social Development}

According to Amartya Sen development should be assessed based on how it expands peoples' capacities and freedoms to do what they value to do. There are instrumental freedoms then that contribute to peoples' overall freedom and capacities: "What a person has the actual capability to achieve is influenced by economic opportunities, political liberties, social facilities, and the enabling conditions of good health, basic education, and the encouragement and cultivation of initiatives" (Sen 1999, 2001:507). In this article, I focus on enabling conditions of health, basic education, as well as poverty and income inequality that are parts of the economic opportunities. For the sake of convenience, I call these aspects of development as social development to distinguish them from notions of political development, or economic development that solely focus on economic growth. 
Different indicators have been used in the analyses of welfare and social developments in Iran. These indicators include life expectancy, infant mortality, literacy, poverty, and income among others. Herein, I discuss their role in the existing literature and how their trendlines compare in the periods before and after the revolution. For some of the indicators, such as infant mortality and literacy, that show continuity before and after the revolution, I present charts that speak to the pace of the change across the two periods. Among the indicators examined in this paper, the data for doctors, hospital beds, and housing are presented for the first time in this article. This is, of course, not an exhaustive list of development indicators, but they still provide a multidimensional picture of social development in Iran before and after the revolution.

The revolution of 1977-1979 occurred at the end of a period of economic growth from the mid- 1950s to the mid-1970s. Following the revolution, Iran entered a period of rapid economic decline. Real GDP per capita dropped to 54\% of its peak in 1976. As Hadi Salehi Esfahani and M. Hashem Pesaran (2009:192-93) write: "Many factors account for this decline, particularly the high political risks for private investors after the Revolution, the exodus of large numbers of skilled professionals, adoption of adverse economic policies, falling oil revenues, and the highly destructive war with Iraq." In an innovative recent article, Mohammad Reza Farzanegan (2020) estimates that as a result of the revolution and war, the average Iranian lost an accumulated sum of about $\$$ US 34,660 over the period of 1978-1988. While GDP per capita is an important indicator for development, there are other non-income indicators that could be more informative about welfare and social development than income. It is noteworthy, however, that income is still relevant to other indicators of welfare, as it provides resources for welfare provision.

Life expectancy is another indicator for social development that can tell us more than GDP about the welfare consequences of the Iranian revolution. Scholars of social development in Iran have examined life expectancy in terms of welfare provision but with contrasting conclusions. 
Drawing on World Bank life expectancy indicators, Harris (2017) argues for the effectiveness of social development in the post-revolutionary period, while Farzanegan (2021) estimates that, as a result of the revolution and war, the average Iranian has annually lost about 6 years of life expectancy over the period of 1978-1988. Why are we observing such a discrepancy in conclusions about post-revolution life expectancy in Iran? This discrepancy seems to result from looking at different indicators of life expectancy and the period of data presentation. Harris (2017:6) only presents the data for female life expectancy and only for the period after 1980, notwithstanding the importance of male life expectancy, including the period before 1980 as well. We observe an upward trend in female life expectancy after the revolution, but, as Figure 1 shows, this upward trend is a continuation from before the revolution. If the country was going through an inclusive social revolution after 1979, or more effective design and implementation of social policies, we would observe a positive rupture in the post-revolutionary period with larger increases in female life expectancy, but the chart shows continuation rather than rupture. Furthermore, as Figure 1 shows, we observe a clear decline in male and overall life expectancy during the period of revolution and war. Farzanegan uses the total life expectancy measure (including both male and female) for his analysis. The charts for male and total life expectancy show a negative rupture, implying destructive effects of revolution and war on the life expectancy of Iranians. The World Bank is a trusted and widely used source of data in cross-national studies on various topics, but it is possible that part of the decline in male and overall life expectancy in Iran might be the result of overestimating the casualties of the Iran-Iraq war. This concern needs additional investigation.

While the decline of overall and male life expectancy after the revolution presents an outright contrast with the idea of a social revolution in Iran, additional examination of female life expectancy also further complicates the argument about an inclusive social revolution in Iran after 1979. If we consider the gradient of the slope for female life expectancy, we can see that the slope is 
steeper before the revolution. To show this, consider Figure 2, which depicts female life expectancy by subtracting the life expectancy of each year from the previous year. This graph shows us the magnitude of the change in female life expectancy for each year.

Figure 1. Life Expectancy in Iran 1960-2018
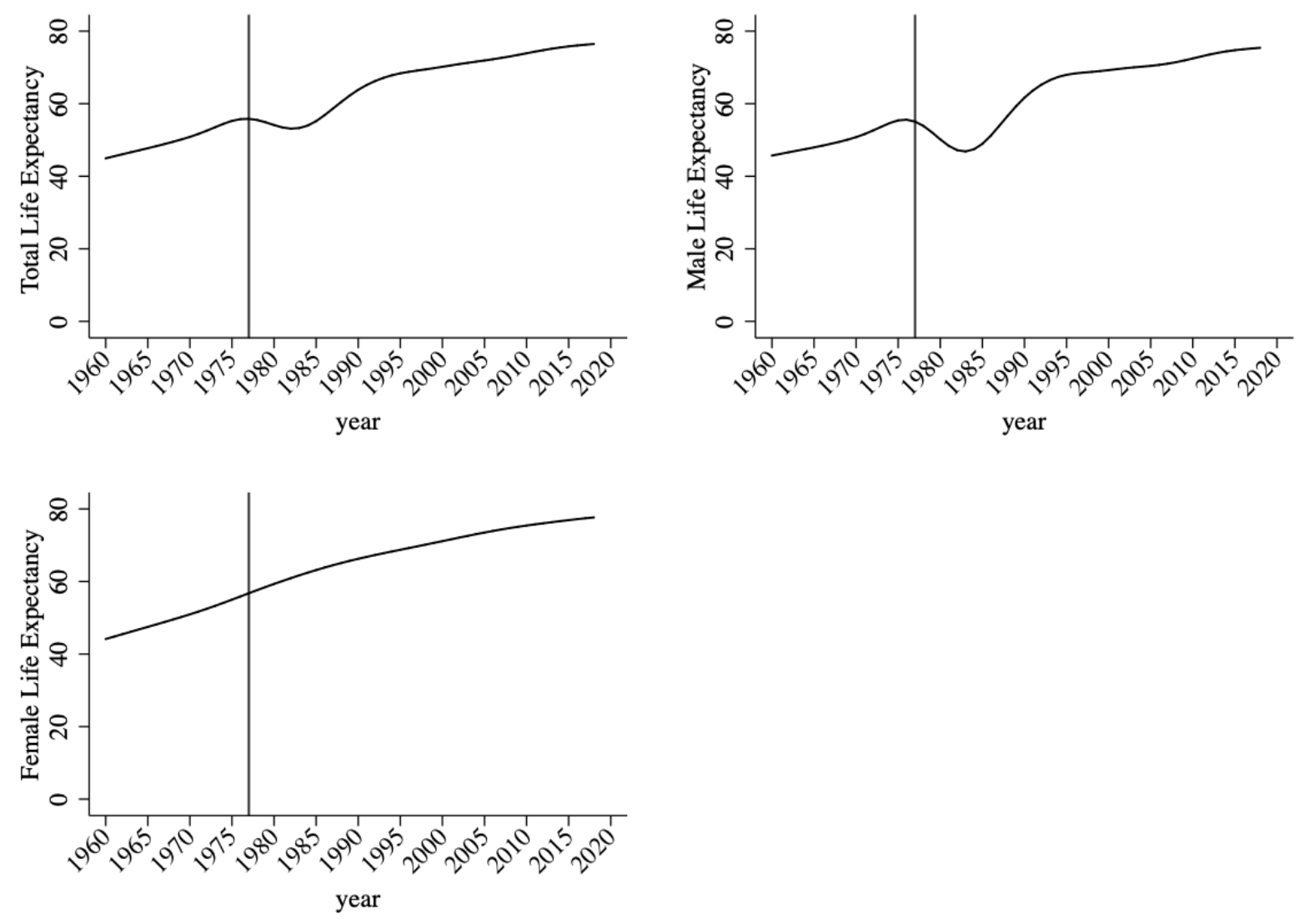

Source: World Bank

Figure 2 shows the observation about the different grades of the slope in a clearer way. In all years before and after the revolution, female life expectancy has been increasing in Iran, but in the pre-1978 period, this increase accelerated, while after 1978, the increase decelerated. If we imagine the state as a car driving on the path to longer female life expectancy, up to 1978, the car has been going forward at greater speed, while the car still goes forward after 1978, but with decreasing speed every year. It is worth noting that the shah's personalist autocratic rule and the limited nature of the 
political process, especially since 1963 rendered his developmental project vulnerable to upheavals such as the 1977-1979 revolution, but the comparison of female life expectancy before and after the revolution further challenges the argument for an inclusive social revolution post-1979.

Figure 2. Improvements in Female Life Expectancy in Iran 1961-2018

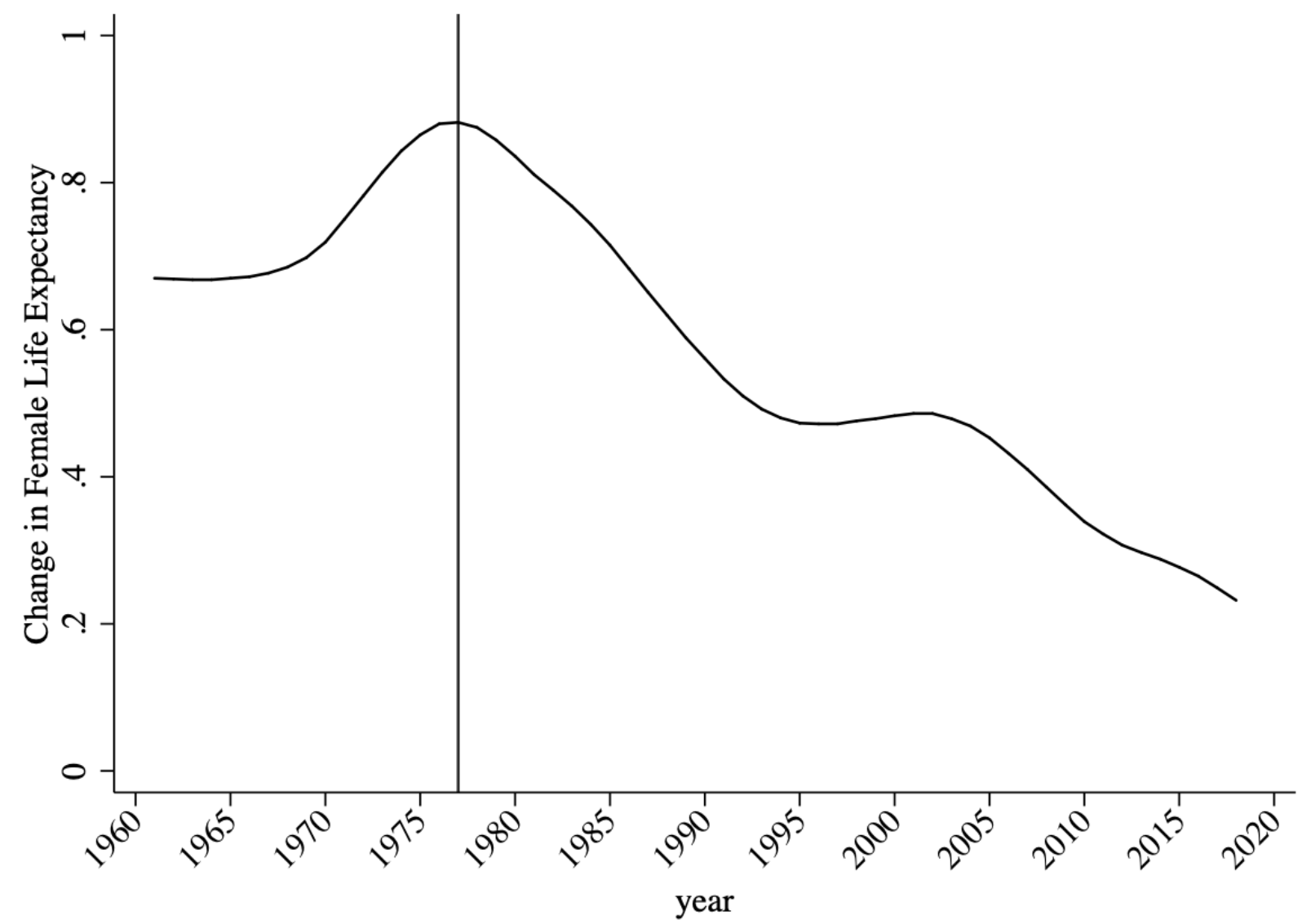

Source: World Bank

The rate of infant mortality is another useful indicator of the state of social development in a country. Figure 3 shows a continuous decline in infant mortality rates before and after the revolution. Harris (2017:8) has presented this data but only for the period after 1980 to support the effectiveness of social development under the Islamic Republic, but to compare pre- and postrevolutionary welfare trends, we must draw on the data from both periods. If we look at the changes 
in the downward trend of infant mortality (see Figure 4), we again observe a turning point around the revolution, which points to the negative effect of the revolution on the expansion of welfare provision. From 1978 onward, infant mortality has decreased in Iran but with a decreasing speed. For both female life expectancy and infant mortality, it is natural for the pace of change to slow down as a country makes more progression, but it is still informative that the turning point from acceleration to deacceleration occurs over the time of the revolution.

Figure 3. Infant Mortality in Iran 1970-2019

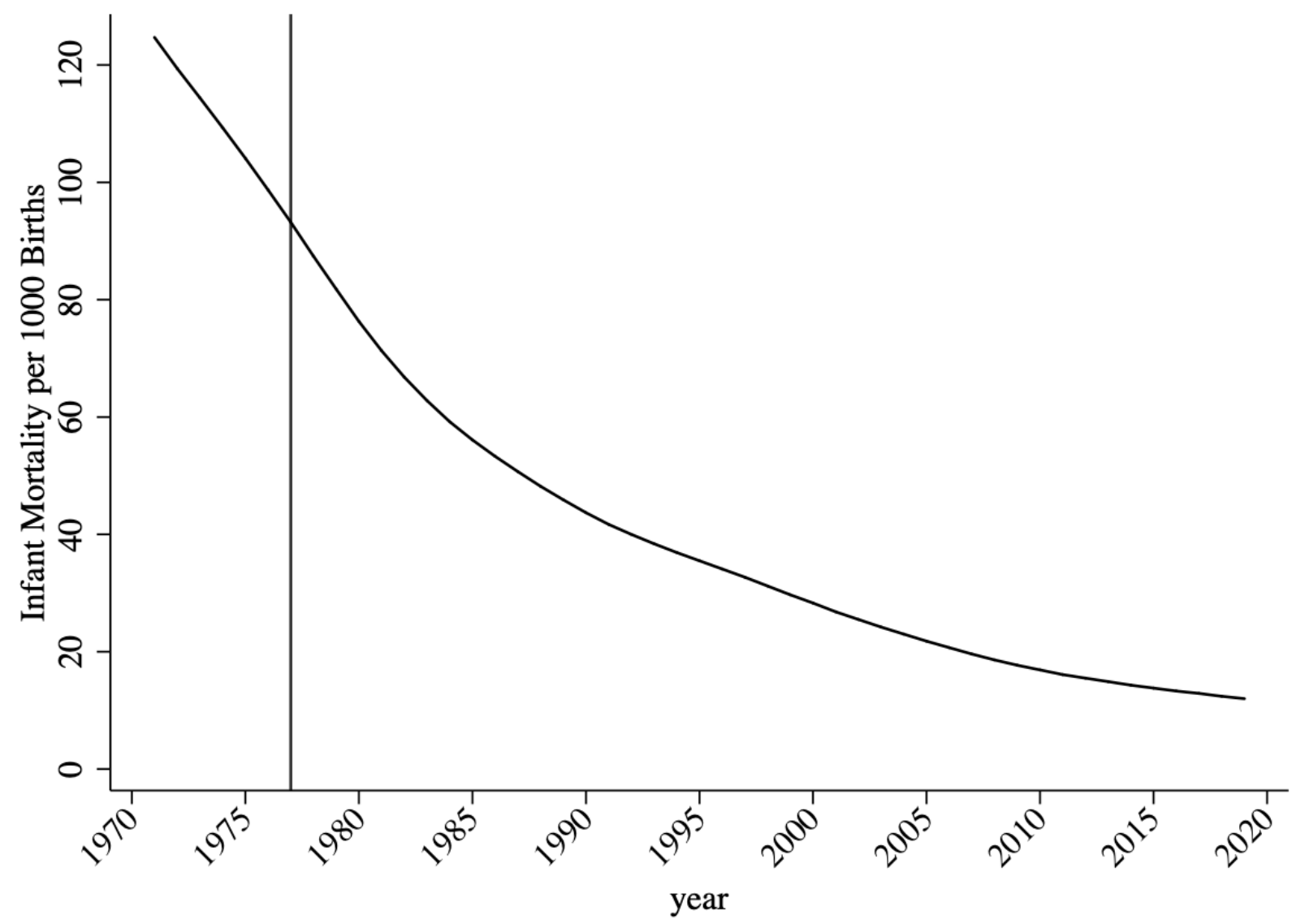

Source: World Bank 
Figure 4. Changes in Infant Mortality in Iran 1971-2019

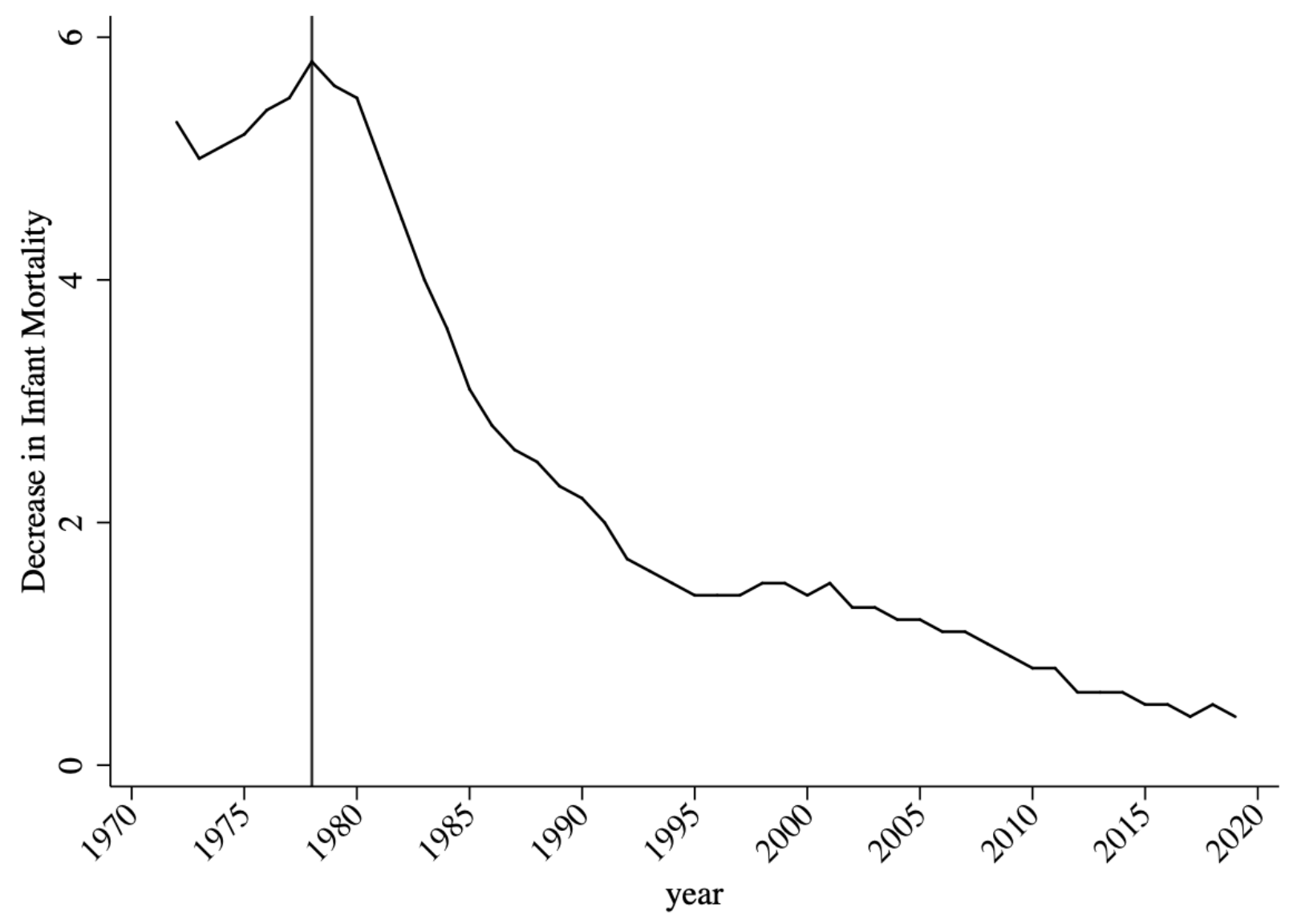

Source: World Bank

Life expectancy and infant mortality are both related to a state's capacity for expanding health institutions and increasing the number of practitioners in the country. Accordingly, we can also measure the rate of increase or decrease in the number of hospital beds and doctors in the country before and after the revolution using data from Iran's Statistical Yearbooks (see Figure 5).

Figure 5 presents the raw number of hospital beds at the bottom and the number of hospital beds per 100,000 at the top. As shown, the ratio of hospital beds to population has increased to 1976, the last year before the revolution for which data is present. In this year, the ratio of hospital 
beds per 100,000 reached 166, but in 1979, the ratio dropped to 149. The ratio of 1976 is not reached again until 2007, about three decades after the revolution.

Figure 5. Hospital Beds in Iran 1965-2015

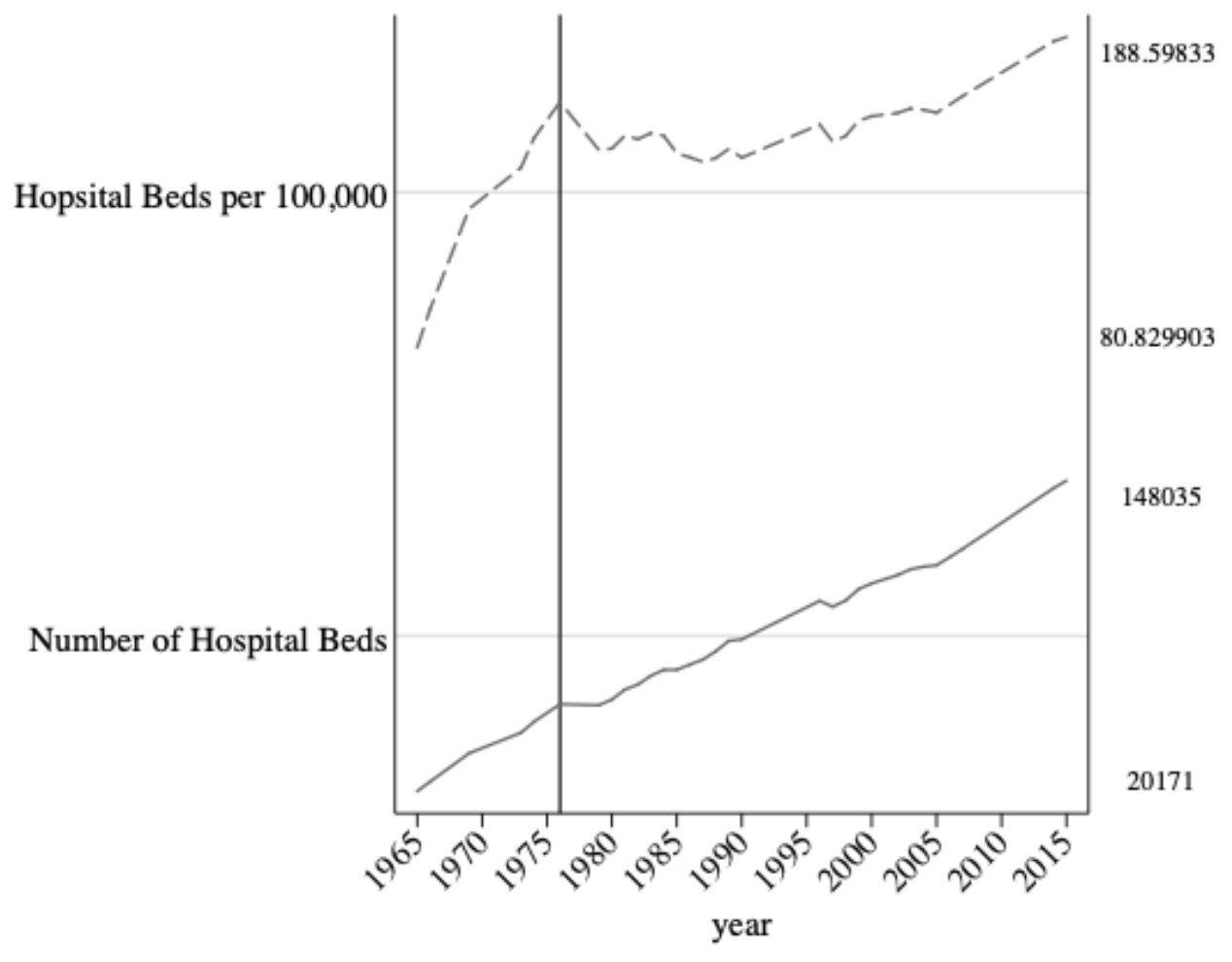

Source: Iran's Statistical Yearbooks (Various Years)

Figure 6 shows a similar pattern to in changes in hospital beds for the number of doctors in the country. As shown, the number of doctors initially peaks in 1979 at 16,937, but then the number starts declining to 9,852 in 1983 . In terms of the ratio of doctors per 100,000, the country does not catch up with the 1979 ratio of 45 until 2006. To show the effectiveness of a health provision under the Islamic Republic, Harris (2017:171) quotes a former health official who claims, as a result of the efforts by the Ministry of Health, "The number of doctors had doubled just during the war years alone." As Figure 6 shows, this is a false claim. This discrepancy between official documents and figures and statements by officials reminds us yet again that statements by officials can at best be 
used as supplementary rather than as substitutes for original documents. Thus far, none of the indicators examined support the idea of an inclusive social revolution post-1979. The period of revolution 1977-1979 marks a turning point across all indicators of life expectancy, infant mortality, the ratio of hospital beds, and the number of doctors, but a turning point from acceleration to deacceleration in positive change, or a clear slowing-down and decline. Rather than strengthening the state capacity, it is evident that the revolution and war have slowed down state performance in some key areas of welfare provision.

Figure 6. Doctors in Iran 1970-2015

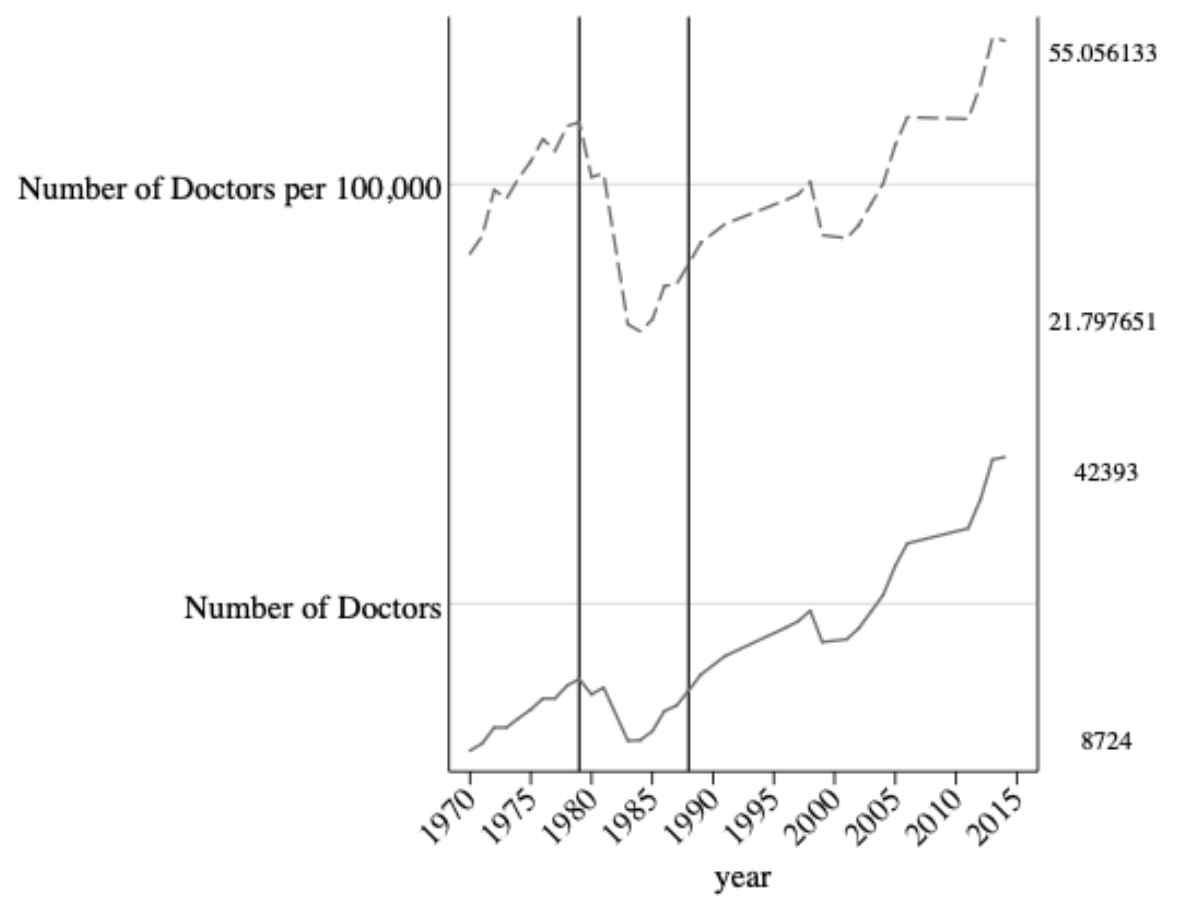

Source: Iran's Statistical Yearbooks (Various Years)

In addition to doctors and hospitals, Harris documents other components of Iran's health system, for example, the expansion of "health houses" [khane-ha-ye behdasht] under the Islamic Republic. Health houses are clinics staffed with health practitioners in both rural and urban areas that provide lower-skill health services locally. Hoodfar (2010) argues that these health houses made 
an important contribution to Iran's population control by providing information and family planning services in rural areas. Harris presents data from Iran's Statistical Yearbooks that show an upward trend in the expansion of health houses and the coverage of the rural population from 1983 onward. While the expansion of health houses under the Islamic Republic is an important achievement, its context is important. The first health house in Iran was founded in 1973 in the village of Qara Chorlu. The main idea for this facility was reliance on a staff of non-doctors to provide primary healthcare. At the time, this was known as the Reza'iye plan, and it was implemented in some other villages as well. According to Yazdani (2020), there were 1,422 health houses in Iran in 1977. In 1978, the Ministry of Health adopted the Reza'iye plan to expand health services throughout the country. ${ }^{2}$ In other words, the plan for the expansion of health houses was developed and adopted prior to the revolution. Given what we see in other indicators such as doctors and hospitals, it is plausible also to consider that the outbreak of the revolution and war might have slowed down the implementation of the plan.

\footnotetext{
${ }^{2}$ For more information on the history of health houses, see the webpage of Urmia Medical University on the topic: https://phc.umsu.ac.ir/index.aspx? fkeyid=\&siteid=9\&pageid=2474
} 
Figure 7. Literacy Rates in Iran 1956-2016
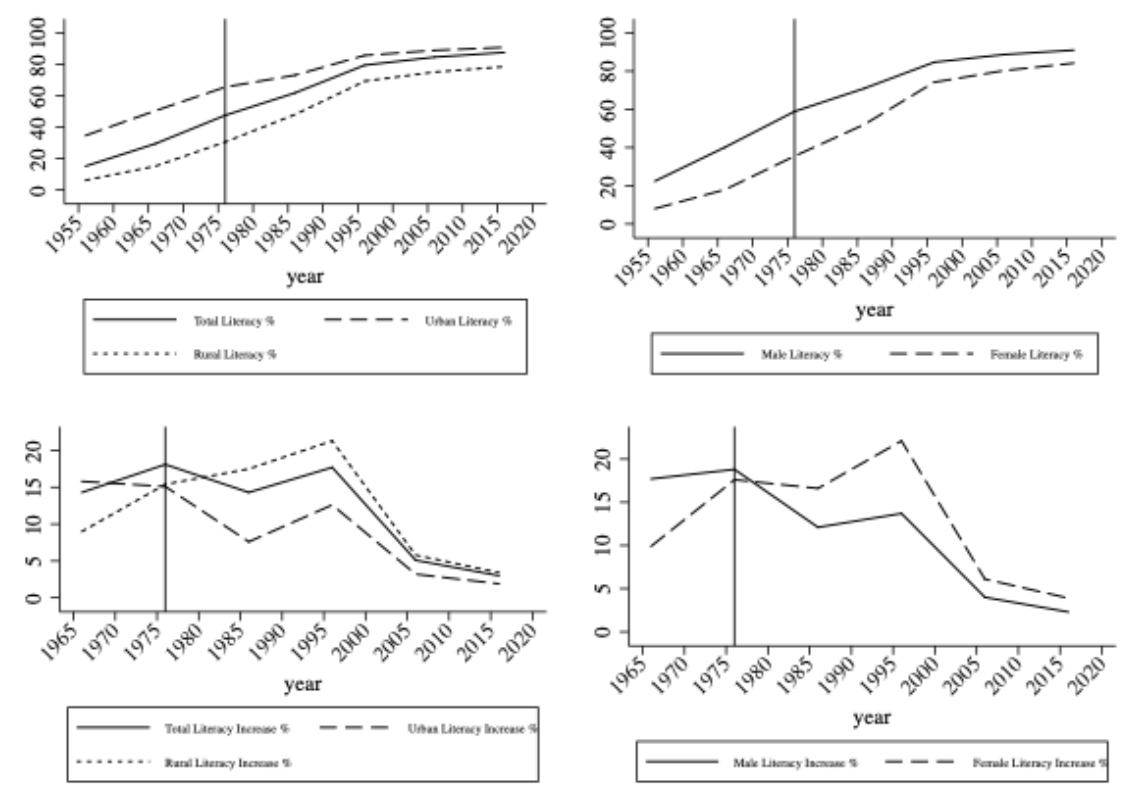

Source: Iran's Statistical Center, Based on Censuses of 1956, 1966, 1976, 1986, 1991, 1996, 2006, $2011, \& 2016$.

Literacy is also an important indicator of social development trends before and after the revolution. The charts at the top of Figure 7 present percentages of the literate population based on existing censuses before and after the revolution. The chart at the top right breaks down the total literacy rate into urban and rural rates as the chart at the top left does for gender. The charts at the bottom show increases in literacy rates for total, urban, rural, male, and female for every decade captured in censuses. In general, the figures show literacy to have been increasing before and after the revolution. In other words, the improvement in literacy after the revolution has been in a continuation of a pre-revolution trend. However, the charts show the literacy gaps between urban and rural and male and female are seen to be decreasing after, but not before, the revolution, thus marking two important improvements in the post-revolutionary period. 
As with life expectancy and infant mortality, it is useful to consider the magnitude of improvement in each period as well. As the graphs at the bottom of Figure 7 show, the largest increases in urban and male literacy occurred before the revolution, during the periods 1956-66 and 1966-1976. In rural and female literacy, however, the largest increases occurred after the revolution, during the periods 1976-86, and 1986-96. In terms of the improvements in total literacy, the preand post-revolutionary regimes seem to be on par, with the largest increase of 18.1\% from 1966-76, and the second-largest increase of $17.7 \%$ from 1986-96. The diminishing gap between urban-rural and male-female literacy rates points to more inclusive literacy campaigns after the revolution. It is noteworthy that the proportion of the urban population to the rural population in Iran has been increasing throughout the last century as Iran has become more of an urban society.

Figure 8. Oil Price, Iran's GDP per capita, and Poverty Headcount

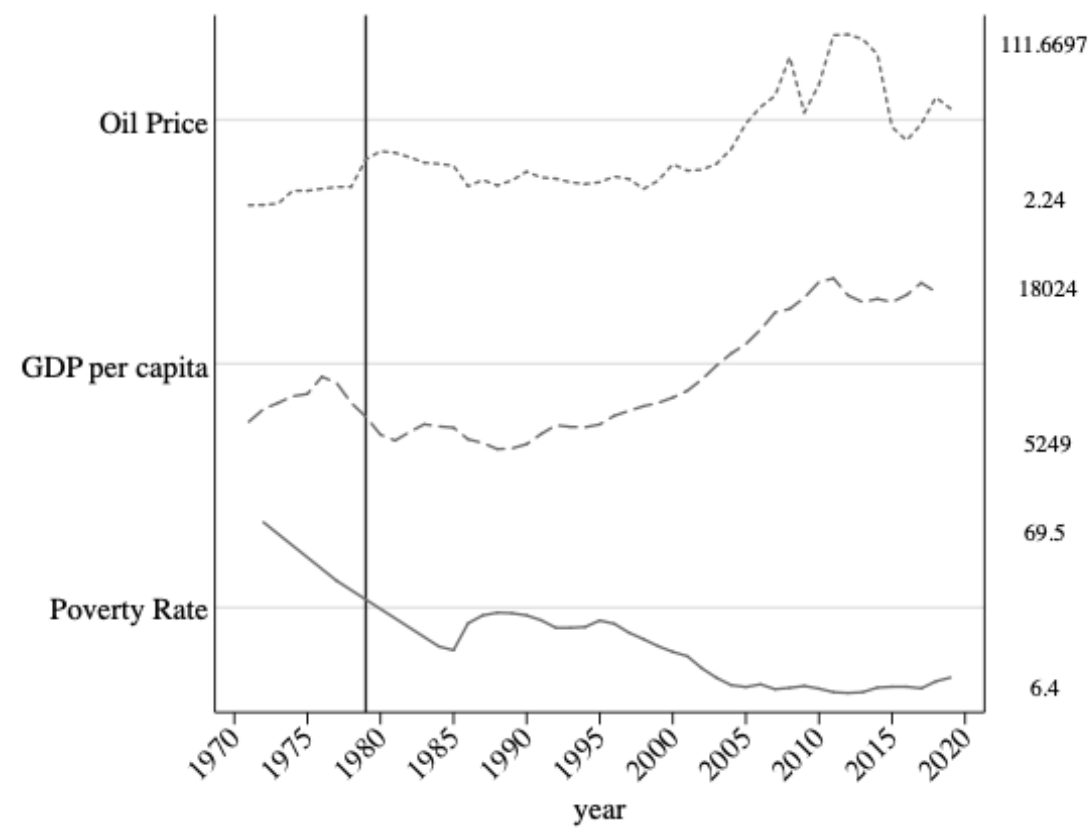

Sources: Our World in Data, Maddison Historical Statistics, Djavad Salehi Isfahani 2019

Note: the main source used to generate the poverty rate is the Household Income and Expenditure Survey that has been conducted in Iran since 1968 at the level of household every year except for 1976, 1979, and 1981. The micro data at the level of household, however, is only available since 1984. The data presented here before 1984 is based on only two data 
points in 1972 and 1977, that Djavad Salehi Isfahani has calculated based on aggregate tables available for those years from Iran's Statistical Center. The data after 1984 is also calculated by Salehi, based on micro data at the level of households.

A number of conclusions can thus far be drawn about social welfare in Iran before and after the revolution. First, we should be looking at multiple indicators, as there might be discrepancies across different policy outcomes. Second, we should examine indicators before and after the revolution. Third, when we observe continuity in an indicator, such as female life expectancy or infant mortality rate, it should consider the pace of change as well. Except for rural literacy, none of the indicators examined here point to a better or more inclusive performance in terms of welfare and development after the revolution. We also know that, after the revolution, there has been considerable improvement in terms of providing services, such as piped water and electricity, to rural areas (Salehi Isfahani 2019). It thus appears that stronger social development improvements after the revolution have occurred in rural areas. What is ironic is that the Iranian revolution was primarily an urban revolution, notwithstanding that its main beneficiaries are the rural population.

Other relevant indicators show effective improvement in the life of Iranians after the revolution. For example, thanks to the efforts of Iranian economist Djavad Salehi Isfahani, we also know that there have been effective reductions in poverty rates (as a percentage of the population living with an average of $\$ 5$ PPP per person per day or less) and enlargement of the middle class after the revolution (Salehi Isfahani 2017). Harris (2017:178) presents Salehi Isfahani's data on poverty rates after the revolution to show the effectiveness of social policies after the revolution. The reduction of poverty from 1995 to 2011 is indeed a considerable policy success. Nonetheless, a contextual note is relevant. The reduction in poverty occurs during a period of economic growth induced by booming oil prices, but the importance of this context is downplayed in Harris's work 
(2017:177), as he says, "Although oil prices are usually associated with welfare outcomes, in theory, through the spoils of rentier-state distribution, poverty trends in Iran do not neatly follow the oil markets." As Figure 8 shows, there is an obvious overlap between rising oil prices, rising GDP per capita, and reduction in poverty. Populist government spending is plausibly an important part of this poverty reduction, but so is oil-induced economic growth. As Salehi (2017:125) writes,

The role of economic growth, which has mostly been oil-induced, is undeniable. When oil prices increased, poverty dropped, whether under the shah or the Islamic Republic. The decomposition of the change in poverty shows that economic growth, especially during the oil boom, has played an important part in reducing poverty. (P. 125)

Reduction of poverty even with reliance on petrodollars is a remarkable achievement, but since such phenomenon has happened also occurred before the revolution, one could ask how the post-revolutionary reduction in poverty during a period of economic growth is similar or different to the same phenomenon during the pre-revolutionary period. Furthermore, when we recognize the role of oil-induced growth in poverty reduction, then we can ask important questions about different policy outcomes and oil-induced economic growth. For example, we observe that oil-induced growth in Iran has paralleled poverty reduction, but we do not see a similar relationship with income inequality. Again, as Salehi Isfahani notes, Iran's policies have not been highly effective in reducing income inequality. As Lob (2018) also points out, Iran's level of inequality is above the Middle East's average, similar to its neighbor Turkey, which has not gone through a revolution with social justice as its main slogan.

Figure 9 presents the trends for income inequality in Iran before and after the revolution. It should be noted that Iran does not have an effective and transparent taxing system. As a result, we lack high-quality data about the extent of income inequality in the country, but the existing data is consistent for comparing pre- and post-revolution data. The existing data for Iran is based on a household survey that the government has been conducting since 1968 and includes extensive detail 
for the income and expenses of the families in the survey. A shortcoming of this data is that it would not include the highest income earners in society because of its sample size (Salehi Isfahani 2017). Better-quality data to examine income inequality is based on government tax receipts (Piketty 2014, 2020).

Figure 9. Income Inequality in Iran 1969-2017

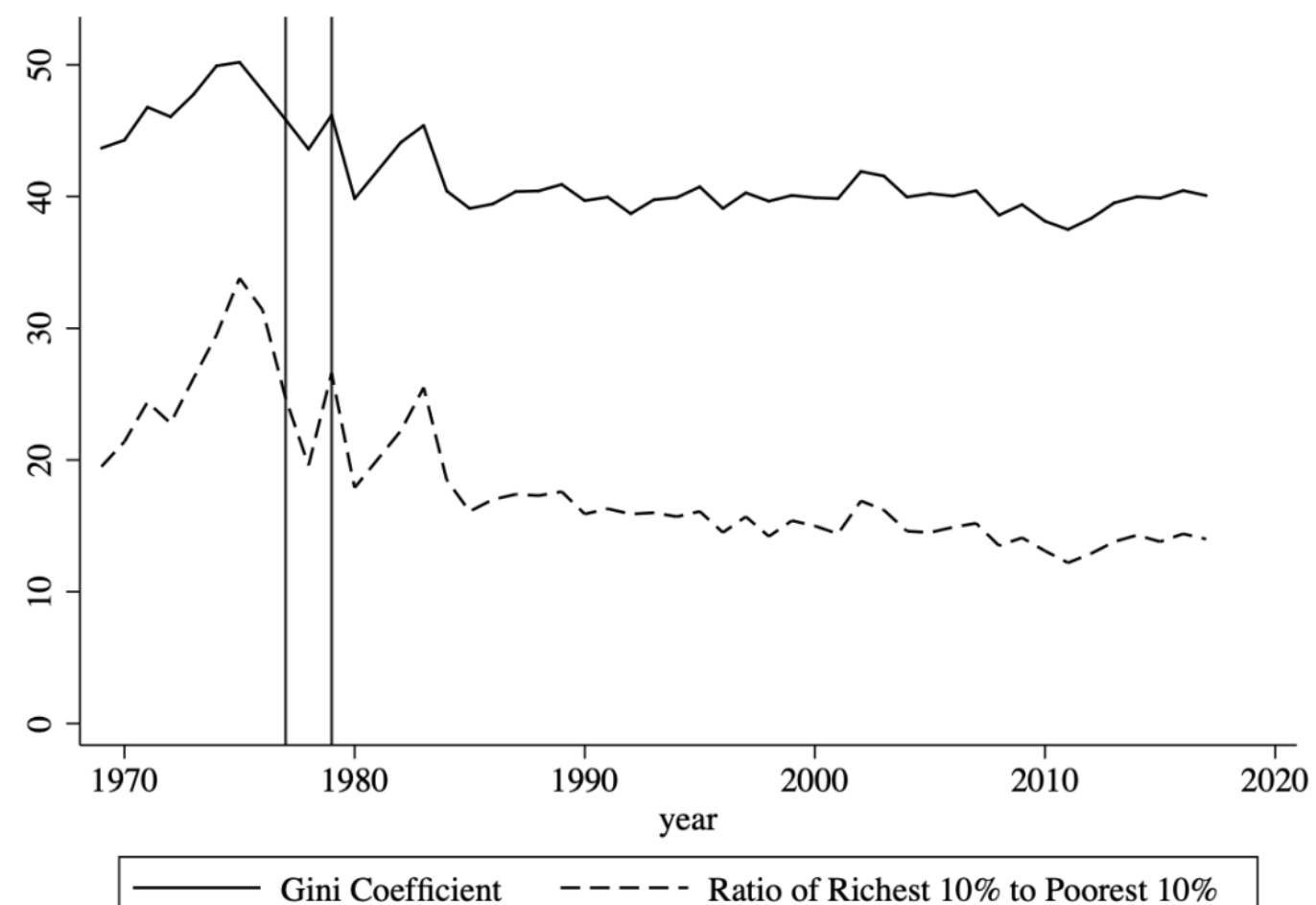

Source: Iran's Central Bank. Both of the indicators presented here are based on the Household Income \& Expenditure Survey.

As Figure 9 shows, the country experienced its highest level of income inequality before the revolution during the oil boom of the 1970s. This is a period during which the shah had solely focused on economic growth without much regard for redistribution. Nonetheless, this level of inequality began to diminish prior to the revolution and was never again reached under the Islamic Republic. We observe another reduction in the level of inequality immediately following the 
revolution, which seems to be the result of the revolution's negative consequences for high earners (Farzanegan and Alaedini 2018:22). As Salehi Isfahani (2017:129) notes,

No doubt the Revolution had a lot to do with the fall in the Gini index, but not because of deliberate economic or social policies. Rather, the upheavals of the Revolution and the war with Iraq caused a disproportional decline in incomes at the top, properties were confiscated, richer families fled, and the war economy and rationing spread. (P. 129)

Scholars have noted a second reduction in income inequality in 2011, which resulted from a cash transfer policy (discussed below). While Iran reached its lowest level of income inequality according to existing indicators, this reduction in the level of inequality did not endure, as is evident from Figure. 9 (Karshenas and Tabatabai 2019). Overall, the record of income inequality was better in the post-revolutionary regime in the sense that it has not reached the high levels of the 1970s. Nonetheless, the trends under the Islamic Republic show continued stagnation and the absence of improvement as a result of redistributive policies.

There are certainly success stories after the revolution. Some of these successes are continuations from the Pahlavi-era policies, as evident in infant mortality and female life expectancy, which continued to decline albeit at a slower pace. Some successes surpass Pahlavi's successes, such as increases in literacy rates in rural areas and among women after the revolution, which does not correspond with economic growth, and there are successes such as poverty reduction, which is related to oil-induced economic growth. Population control and reduction in fertility rates are among other post-revolutionary successes (Abbasi-Shavazi, McDonald, and Hosseini-Chavoshi 2009; Ladier-Fouladi 1997). The leaders of the Islamic Republic adopted this policy of population control after they had dismantled Iran's new population control policy in the first years of the revolution, which had resulted in a sudden increase in the population growth in the country (Hoodfar 1994; Hoodfar and Assadpour 2000). At the same time, there are welfare policy failures after the revolution, such as the government's performance in creating jobs (Salehi Isfahani 2019), 
some areas of health provision, and housing ${ }^{3}$ (see Figure 10 for the rate of homeowners and renters before and after the revolution). As the decline in the number of doctors and hospital beds per 100,000 ratio shows, the revolution has resulted in state capacity decline in providing some health services to the population.

Figure 10. Percent of Homeowner and Renter Households in Iran (1956-2016)

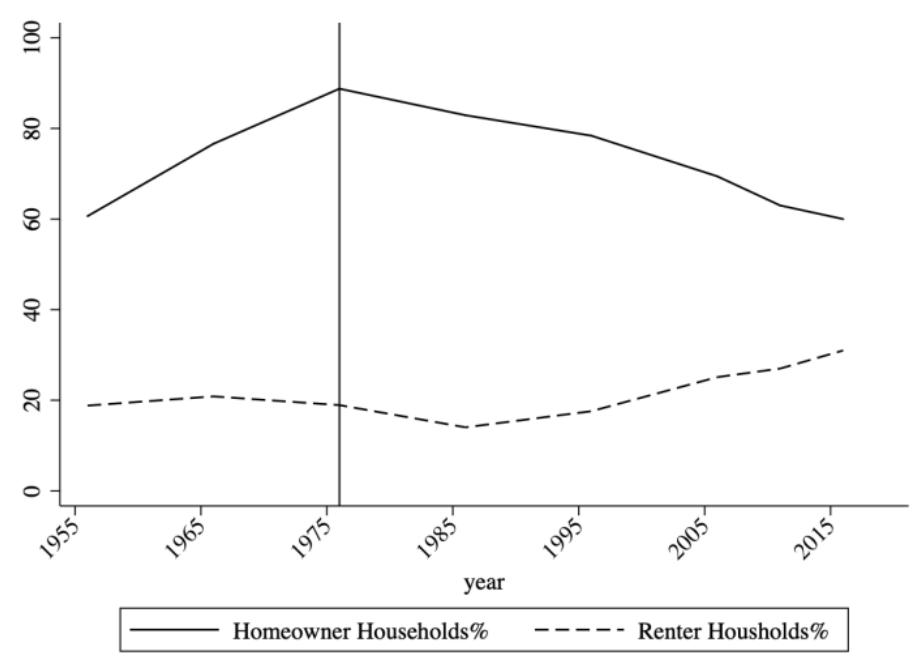

Source: Iran's Statistical Center, Based on Censuses of 1956, 1966, 1976, 1986, 1996, 2006, 2011, \& 2016.

To reflect the complexity and heterogeneity of different policy outcomes before and after the revolution, we need to go beyond categories such as inclusive and exclusive. In her ethnographic analysis of only women spaces in Tehran, sociologist Nazanin Shahrokni (2019) presents an alternative approach through concepts of "differential inclusion/exclusion", arguing how policies could have both inclusionary and exclusionary outcomes simultaneously or at different points in time. The mixed results of policy outcomes and the decline in some important state performances reviewed here present more of a challenge to the expectations drawn from Skocpol's theory about

\footnotetext{
${ }^{3}$ Rising house prices over last four decades has been identified as a major contributor to income inequality in postrevolutionary Iran (Farzanegan, Gholipour, and Nguyen 2016).
} 
the social effects of revolutions and wars. Rather than expecting a full improvement or decline along with all development outcomes, it might be theoretically and empirically more fruitful to examine these areas separately and then try to understand the overall transformations in social development as a result of revolutions.

Overall, it appears that the argument presented for an inclusive social revolution after 1979 (Harris 2017) is based on a vaunted picture of the post-revolution success stories without providing the requisite background and context. As Iranian political economist Mohammad Maljou has suggested, the adoption of such a foundation introduces a systematic selection bias in the argument for better social development and health provision after the revolution and war. In his response to Harris' book, Maljou states that the argument for an inclusive social revolution after 1979 rests on underreporting welfare under Pahlavi and exaggerating welfare provision after the revolution. After one accounts for these two errors, Maljou says, "the idea of an inclusive social revolution to a large extent melts into air like smoke” (IBNA 2019). Furthermore, a recent review of Harris' book by Farshid Yazdani (2020), a researcher in Iran's social policy, points to many factual inaccuracies and errors in the argument that exaggerate development performance after the revolution and understate development performance before the revolution. For example, Harris underreports individuals covered by insurances in Iran before the revolution (P. 61) and Iran's GNP for the 1960s, overreports the size of the family before the revolution (P. 126), which results in an exaggeration of the reduction in infertility rates after the revolution and underreports the reduction in legal age for marriage after the revolution (P. 133), among others.

\section{Politics and Social Development After 1979}

Thus far, I have argued that existing evidence does not support an overall improvement in social development and state capacity in Iran after the revolution, contrary to the expectations of theories about the positive effect of social revolutions on states' developmental capacity (Skocpol 
1979, 1995). Nonetheless, it is still worthwhile to consider how post-revolutionary politics have affected social development and the state in Iran. Even though repression, exclusion, and authoritarianism remained as predominant features of Iranian politics after the revolution, the configuration of Iranian politics underwent drastic changes after the 1979 revolution.

First, elite competition and factionalism drastically increased in Iranian politics compared with 1963-77. The factional feature of Iranian politics is a widely recognized dynamic in Iran after 1979 and has been the subject of scholarly analysis and investigation (Ayatollahi Tabaar 2018; Keshavarzian 2005; Moslem 2002). Second, the level of popular mobilization in Iran again has increased since 1977. This mobilization has manifested itself both in anti-government mobilization using armed and unarmed methods and mobilization by and within the state. During the 1980s, war mobilization by the state and insurgent mobilization against the state were the main forms of popular mobilization. Since the 1990s, electoral mobilization has also become an important dynamic within Iranian politics. Scholars of Iranian politics have examined the dynamics of different episodes of contention and the interaction of popular mobilization and elite politics through different postrevolutionary periods (Alemzadeh 2018; Kadivar 2013; Kadivar and Abedini 2020; Mashayekhi 2001; Moghadam and Gheytanchi 2010; Rivetti 2020). Third, Iran's foreign policy has become more confrontational since 1979, and Iran has been part of more regional and international conflicts post1979. Scholars have disagreed on the source of this greater level of conflict, but the higher level of Iran's engagement in regional and international conflict is a fact recognized by scholars of Iran's foreign policy and international relations (Byman et al. 2001; Ramazani 2013; Walt 1997). While these changes are widely known among the scholars of Iranian politics, the manner in which they have affected policy outcomes is the subject of debate and disagreement. Furthermore, since the results for post-revolutionary social development outcomes vary in terms of improvement or 
decline, it is analytically necessary to consider how each of these mechanisms has served or undermined social development after the revolution.

Regarding factionalism, one approach contends that increased elite competition after the revolution has contributed to further expansion of the welfare state and a more inclusive social development. An important mechanism in this approach is the emergence of parallel welfare institutions due to factional competition (Harris 2017). Plausibly, to gain popular support, different factions have sought to expand welfare provision in their competition with other factions, although this hypothesis requires further specification and empirical evidence. On the other hand, it is also plausible that factions block each other's policies in programs for similar reasons. Furthermore, factions are likely to pack state bureaucracies with their cronies to expand their access to the spoils of the office. Such a mechanism is likely to undermine bureaucratic performance and increase corruption. For example, we know from the work of political economists that factionalism may harm economic growth (Kjetil, Farzanegan, and Friedrich 2013). Or, as Nazanin Shahrokni (2019) in her sophisticated and informative study about women's demand to access sports stadiums in Iran shows, factional politics becomes detrimental to this cause as each faction does not want the other faction to take credit for giving women access to sports stadiums. The example of cash transfers in 2011 would be telling here as well. In 2011, Iran started a direct cash transfer program under President Ahmadinejad, which resulted in a noticeable reduction in income inequality in the country (Salehi Isfahani 2017). This cash transfer was related to reforms in energy subsidies, a policy that was discussed in Iran some years before the adoption of the policy. The Khatami administration before Ahmadinejad tried to start the subsidy reforms, but the process stalled due to resistance from the conservative parliament at the end of Khatami's administration. There were debates in the country as to whether to adopt a targeted cash transfer after subsidy reforms or to have a universal cash transfer. In 2005, Mehdi Karrubi, a reformist candidate, proposed in his electoral campaign a 
universal cash payment to each Iranian citizen. Nonetheless, Karrubi was not a winner of that election, and his electoral promise was not fulfilled. Karrubi objected to irregularities in the vote count, but his complaints fell on deaf ears. Ahmadinejad was the winner of that election. In 2011, finally, both subsidy reforms and cash payments were implemented, and under Ahmadinejad's presidency, the government also decided to conduct a universal cash transfer.

How the policies were developed, blocked, and postponed in the context of the elite competition is noteworthy. Furthermore, when the reforms in energy subsidies finally occurred, when the state had become more unified after 2005 as conservatives had dominated both the executive and the legislature. In other words, at this time, factionalism had diminished within the state, as reformists lost control of the legislature and executive in 2004 and 2005. The conservatives then implemented policies that reformists had developed and promoted earlier. ${ }^{4}$

It has been claimed that revolutionary and post-revolutionary popular mobilizations have contributed to the expansion of welfare in Iran. For example, it has been claimed that the universal cash transfers of 2011 has been the result of the 2009 Green Movement protests, although this claim lacks empirical support (Harris 2017). A more developed and specified version of this argument is presented by Lob (2020) about Reconstruction Jahad (RJ) and its health and literacy campaigns in rural areas. RJ was a revolutionary organization formed in 1979 after the fall of the monarchy that allied with Islamists and focused on rural development. Lob’s argument about the developmental campaign of RJ in rural areas corresponds to post-revolutionary achievements in the expansion of

\footnotetext{
${ }^{4}$ Similar to the outcome of development and welfare, it would be important to also utilize primary sources related to elite competition and mobilization as potential drivers of social development. For example, the main publicly available sources for investigating Iran's factional politics are the proceedings of the parliament, where different factions debate and ratify all bills related to welfare and social policy. Other windows onto Iran's elite politics are the memoirs written by the leaders and top elite of the Islamic Republic, such as those of Hashemi Rafsanjani-a member of the revolutionary council, speaker of the parliament, Iran's president, and head of the expediency assembly through different stages of Islamic Republic's political life. Among recent analyses of Iranian politics, Mohammad Ayatollahi Tabaar's (2018) analysis of Islamists' politics is an example of research that has utilized a variety of first-hand documents in the analysis of Iranian elite politics.
} 
literacy in rural areas presented in Figure 8. Lob argues that, in addition to health and development provisions, RJ also attempted to drive leftist organizations from rural areas. At the same time, Lob pays attention to the exclusionary efforts of an organization, such as RJ, in tandem with their developmental efforts to include the rural population in its access to different developmental services. Accordingly, one can also investigate other detrimental effects of the intense mobilizations of the 1980s. In another important analysis of mobilization and social policy, Hoodfar (2010) documents how mobilization of about a hundred thousand voluntary female health workers were integral to Iran's success in implanting the population control policy. Furthermore, these volunteers contributed in improving the provision of different services and health conditions in their communities. While these volunteers expressed interests in expanding their activities and to maintain their volunteer network for further deliberation, the officials dismissed such initiatives and did not facilitate the formation an independent social organization out of this vast network of female volunteers. This is an important observation as it shows how the state both facilitated the mobilization, and hindered the formation of an independent civil society organization based on the mobilization.

In addition to the positive effects of popular mobilization for social development, a comprehensive account of mobilization and social development would also consider how mobilization has contributed to Iranian loss of life, particularly for young men in the 1980s—a decade of intense political violence. During 1977-79, the monarchy killed about 2,000 peoplemostly men—during street protests. During the Iran-Iraq war, about 180,000 people were killed. Many members of insurgent groups such as Mojahedin-e Khalq and Kurdish fighters were killed in armed clashes with government forces. Furthermore, the Iranian government executed thousands of opposition members from leaders to rank and file from royalists, leftists, and ethnic and religious minorities such as Bahai's. It is thus reasonable to consider lives that were lost during the 
mobilizations from 1977 to $1988 .^{5}$ At the same time that serious efforts were undertaken in the country to improve the life of Iranians in rural areas through education and service provision, lives were being lost to mobilization. The level of popular mobilization in Iran has increased since 1977, but so has the level of repression and political violence.

In addition to physical harms and resentments caused by popular mobilizations in 1977-1988 (Ehsani 2016), the psychological consequences of the trauma experienced during post-revolutionary mobilization and violence are also valid topics for investigation. In her ethnographic study of the psychiatric discourse within Iranian institutions, Orkideh Behrouzan (2016) documents how in the 1990s, after the end of the war, a psychiatric discourse emerged in Iran around rising psychological problems such as heightened levels of depression among the urban population. Consistent with Behrouzan's argument, Figure 11 presents data from Iran's Statistical Yearbooks about the rate of suicide in the country for the period 1968-2015. As shown, there is a rapid increase in suicide rates in the years following the revolution, as the suicide rate of about 10 people per million increases four times to a suicide rate of over 40 people per million. This increase in the suicide rate is consistent with the existing literature about the effect of war on suicide rates (Marshall 1981). For example, an analysis of suicide in Northern Ireland finds that the cohort of children and young people that grew up during the period of most intense violence have, in contrast to earlier and later cohorts, the highest levels and the most rapidly increasing suicide rates (Tomlinson 2012). The relationship of war and suicide in Iran thus also deserves further attention and investigation.

\footnotetext{
${ }^{5}$ Human rights organizations have documented these executions at that time(for example see Amnesty International 1980; Amnesty International USA 1983). Another human right organization, the Boroumand Foundation has compiled the most comprehensive list of dissidents executed after the revolution: https://www.iranrights.org/fa/memorial/browse/date For the mass executions of 1988, also, see Mohajer (2020).
} 
Figure 11. Suicide Rate in Iran 1968-2015

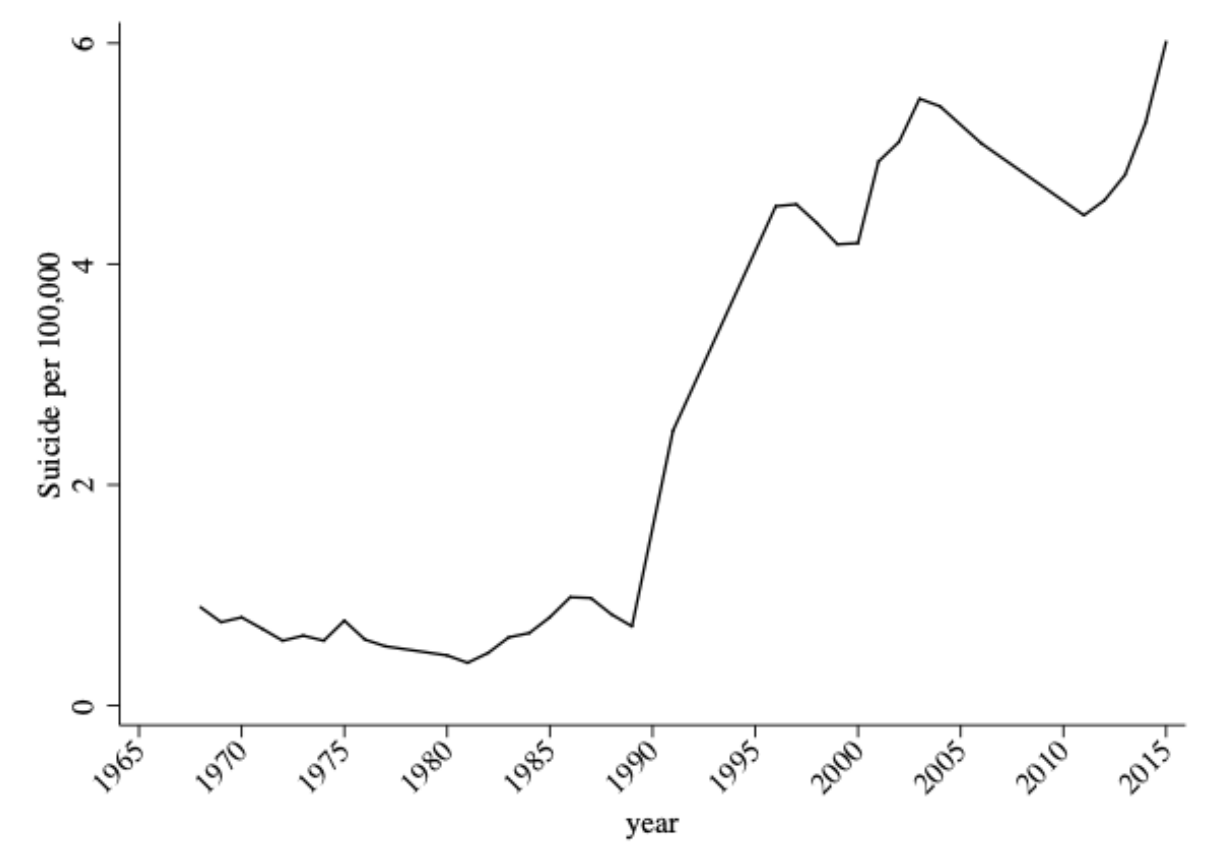

Source: Iran's Statistical Yearbooks (Various Years)

Finally, in terms of the effect of foreign policy on social development, one approach contends that the Islamic Republic's anti-systemic tendencies in its international politics have provided strong motivations for the country's leadership to pursue developmental policies (Harris 2017). Movahed (2020), for example, documents how Iran developed and expanded a dynamic auto industry under sanctions. Similarly, part of the Islamic Republic's leadership has maintained on occasions that superpowers can do no wrong to the country, and that sanctions are ineffective in harming Iran's economy. Iran's leader, Ali Khamene’i, for example has called the sanctions a blessing for the country and maintained that "sanctions cannot harm us ... under some conditions, sanctions can even benefit us; because it increases our efforts and activities” (BBC Persian 2016). Critics of Iran's foreign policy within Iran and scholars of political economy, however, have highlighted the high economic cost of international confrontations for the country, specifically in the 
form of sanctions imposed on Iran's oil and banking sectors. This approach documents the negative effect of sanctions on the economic growth in formal and informal sectors and the detrimental effects on household welfare among different income groups (Farzanegan and Hayo 2019; Farzanegan, Khabbazan, and Sadeghi 2016; Shahrokni 2021). Both before and after the revolution, Iran has pursued developmental projects, but post-revolutionary, confrontational foreign policy has limited such efforts in important ways. Sanctions, of course, reflect an unequal world system, in which superpowers impose sanctions against less powerful countries, but it is also undeniable how a faction within the Islamic Republic has sought confrontation and escalation with the US to promote their factional interests (Ayatollahi Tabaar 2018). ${ }^{6}$

\section{Conclusion}

The effects of revolutions and war-making on state-building projects have been an important area of inquiry within comparative historical analysis. For example, in his seminal work about states and wars, Charles Tilly (1992) has argued that wars make states, and states make war. Similarly, in her influential book about social revolutions, Skocpol (1979) has contended that social revolutions in France, Russia, and China strengthen centralization and state capacity in the respective countries. Finally, in her analysis of the welfare in the US, she (1995) documents how providing for the soldiers of the American Civil War and their families became an important source of social policy in the U.S. Accordingly, one can think of extending such arguments to the case of Iran to claim that the 1979 revolution and Iran-Iraq war culminated in a social revolution in Iran imagined to give rise to broad and inclusive social development and welfare for the population. Nonetheless, as the evidence reviewed in this essay shows, the consequences of the revolution and war for social development do

\footnotetext{
${ }^{6}$ A recent leaked tape of Iran's former foreign minister Javad Zarif for example shows how after reaching the nuclear deal, the Revolutionary Guards were adopting provocative and escalating measures, despite objections from the Foreign Ministry. Zarif's remarks indicates that the moderates in the government did not have the capacity to control the Guards, and the Guards had the upper hand in setting Iran's foreign policy regarding Syria and Iraq (Fassihi 2021).
} 
not fit the theoretical expectations driven by these studies. There is evidence that state capacity and performance in some areas of social development have slowed after the revolution. Instead of trying to fit the case of Iran to the theoretical expectations of these studies, it would be theoretically more fruitful to use the case of Iran to correct and revise these classic studies about the social consequences of revolutions and wars. More specifically, we can ask in what areas the revolution and war strengthened state capacities versus undermining them. Subsequently, we can enquire through which simultaneous mechanisms and processes, revolution and war undermine, strengthen, or reshape state-building projects. The dimensions of social development examined in this article are, of course, not exhaustive. Future research shall look into other indicators not examined here such as social spending versus military spending, addictions and narcotic consumptions, and informal housing, among others.

Among different development indicators reviewed in this article, the indicators for the ratio of doctors and hospital beds to the population are directly related to the current Covid epidemics that the world and Iran have been suffering since 2020. The examination of these indicators shows a decline in the post-revolution years. Existing cross-national research indicates a significantly negative correlation between cumulative death rate due to Covid and the number of hospital beds (Su et al. 2020). Based on these findings, one can make a case that the post-revolutionary decline in some areas of health provision has contributed in high number of deaths due to covid in Iran. Currently, the official number of Covid deaths in Iran has surpassed 110,00 (Farsnews 2021). According, the officials in the Ministry of Health, the real number of deaths is about two times bigger (BBC Persian 2021), which brings us to more than 220,000 deaths in year and half. This large number of covid death has surpassed the number of Iranians that were killed during the eight years of the Iran-Iraq war (about 180000). The government plan for vaccination has been also very ineffective thus far. The total percent vaccinated in Iran is about $22 \%$ by early September 2021 , while the neighbor 
country of Turkey has vaccinated more than $58 \%$ of the population. The state failure in the vaccination program is also relevant to discussion about the performance of parallel institutions and development outcomes. Initially, government institutions announced the development and domestic production of five different vaccines in the country, or in collaboration with Cuba and Russia. One of these vaccines was supposed to be developed by The Executive Headquarter of the Imam's Decree (EHID) one of the parallel institutions under the authority of Iran's Leader. Given this institution's connection with the leader's office and other centers of power, other vaccines were faced with hurdles and impediments. The plan to import vaccines was also postponed to support the future mass production of this vaccine for the domestic market (Roozarooz 2021). Reflecting the Islamic Republic's confrontational foreign policy, Iran's leader Ali Khamenei also announced that he did not trust the American and British vaccines, and put a ban on the import of those vaccines. Mohammad Mokhber the head of the EHID promised in multiple occasions to produce and distribute millions of doses of this vaccine in the country, but none of the promises were kept (Rouydad24 2021). While the performance of Mokhber and his organization in vaccine production was an utter failure, in the summer of 2021, Mokhber was appointed as the vice president for the new president Ebrahim Raisi, and the government announced its new policy for prioritizing vaccine imports, despite all the earlier promises that had been made by Mokhber and others. With the increasing number of deaths and hospitalization with the advent of the delta variant, many Iranians who lost loved ones expressed frustration about government failure in its vaccination policy. The public criticisms of the government performance in regard to vaccination program has been so high that, Iran's ministry of education revised textbooks that had earlier praised Iran's effective containment of covid (ISNA 2021). The account of the government failure to roll out an effective vaccination program then serves as another important example for how parallel institutions and factionalism have hindered effective policy making and government action. 
The approach presented here to assess the outcomes of the Iranian Revolution could be adopted to investigate the outcome of other revolutions as well, for example, the classic cases of China, Russia, and France, or later revolutions of the $20^{\text {th }}$ century such as Nicaragua, Algeria, and Mozambique. New data and research show that it is more accurate to consider the heterogeneity of outcomes in the classic cases examined by Skocpol rather than assuming consistent improvement or decline across all indicators. For example, it seems that the French revolution strengthened state bureaucracy but left major patterns of income inequality intact (Piketty 2020). Or, in China, the revolution resulted in a state with impressive developmental performance, but there is also evidence pointing to the detrimental effects of the Cultural Revolution (1966-1976) for health and educational outcomes (Fan 2016, 2017). Future research can provide case studies of revolutionary outcomes based on various indicators and discussions of mechanisms linking revolutionary processes and developmental outcomes. Based on such case studies, then, scholars of revolutions and their outcomes could present comparisons between cases and generalize statements documenting the commonalities and differences in terms of outcomes and mechanisms. 


\section{Bibliography}

Abbasi-Shavazi, Mohammad Jalal, Peter McDonald, and Meimanat Hosseini-Chavoshi. 2009. The Fertility Transition in Iran: Revolution and Reproduction. 2009th edition. New York: Springer.

Abrahamian, Ervand. 2009. "Why the Islamic Republic Has Survived.” Middle East Report 250.

Alemzadeh, Maryam. 2018. “The Islamic Revolutionary Guards Corps in the Iran-Iraq War: An Unconventional Military's Survival.” British Journal of Middle Eastern Studies 0(0):1-18. doi: 10.1080/13530194.2018.1450137.

Ameli, Vira. 2020. "Sanctions and Sickness." New Left Review (122):49-57.

Amnesty International. 1980. Law and Human Rights in the Islamic Republic of Iran: A Report Covering Events within the Seven Month Period Following the Revolution of February 1979. London: Amnesty International.

Amnesty International USA. 1983. Amnesty International Documentation on Iran: Human Rights Violations in Iran, Sept. 7, 1982 : Ill-Treatment of Prisoners in Iran, Dec. 9, 1982. New York, N.Y.: U.S. Section, Amnesty International.

Ayatollahi Tabaar, Mohammad. 2018. Religious Statecraft: The Politics of Islam in Iran. New York: Columbia University Press.

BBC Persian. 2016. “رو BBC News "روايتى از تحريم ايران: وقتى آيتالله خامنهاى از آمريكا تشكر كرد." Retrieved September 4, 2021 (https://www.bbc.com/persian/iran/2016/05/160430_139_file_khamenei_sanctions).

BBC Persian. 2021. “ " BBC News فارسى

Beck, Colin. 2017. "Revolutions: Robust Findings, Persistent Problems, and Promising Frontiers." Pp. 168-83 in States and Peoples in Conflict, edited by M. Stohl, M. I. Lichbach, and P. Grabosky. New York: Routledge.

Beck, Colin J. 2020. "Revolutions Against the State." Pp. 564-91 in The New Handbook of Political Sociology, edited by T. Janoski, C. de Leon, J. Misra, and I. W. Martin. Cambaridge, UK: Cambridge University Press.

Behrouzan, Orkideh. 2016. Prozak Diaries: Psychiatry and Generational Memory in Iran. 1st ed. Stanford, California: Stanford University Press.

Burawoy, Michael. 1989. "Two Methods in Search of Science: Skocpol vs. Trotsky.” Theory and Society 18(6):759-805.

Byman, Daniel, Shahram Chubin, Anoushiravan Ehteshami, and Jerrold D. Green. 2001. Iran's Security Policy in the Post-Revolutionary Era. Santa Monica, CA: Rand Corporation. 
Ehsani, Kaveh. 2016. "War and Resentment: Critical Reflections on the Legacies of the Iran-Iraq War.” Middle East Critique 0(0):1-20. doi: 10.1080/19436149.2016.1245530.

Fan, Wen. 2016. "Turning Point or Selection? The Effect of Rustication on Subsequent Health for the Chinese Cultural Revolution Cohort." Social Science \& Medicine 157:68-77. doi: 10.1016/j.socscimed.2016.03.044.

Fan, Wen. 2017. "Education Delayed but Not Denied: The Chinese Cultural Revolution Cohort Returning to School." Advances in Life Course Research 33:53-65. doi: 10.1016/j.alcr.2016.09.004.

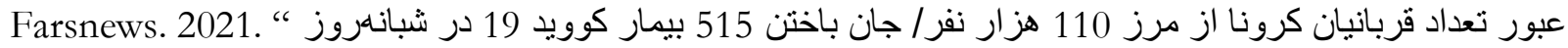

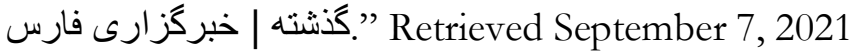
(https://www.farsnews.ir/news/14000613000584/\%D8\%B9\%D8\%A8\%D9\%88\%D8\%B1 $\% \mathrm{D} 8 \% \mathrm{AA} \% \mathrm{D} 8 \% \mathrm{~B} 9 \% \mathrm{D} 8 \% \mathrm{AF} \% \mathrm{D} 8 \% \mathrm{~A} 7 \% \mathrm{D} 8 \% \mathrm{AF}-$

$\% \mathrm{D} 9 \% 82 \% \mathrm{D} 8 \% \mathrm{~B} 1 \% \mathrm{D} 8 \% \mathrm{~A} 8 \% \mathrm{D} 8 \% \mathrm{~A} 7 \% \mathrm{D} 9 \% 86 \% \mathrm{DB} \% 8 \mathrm{C} \% \mathrm{D} 8 \% \mathrm{~A} 7 \% \mathrm{D} 9 \% 86-$

$\% \mathrm{DA} \% \mathrm{~A} 9 \% \mathrm{D} 8 \% \mathrm{~B} 1 \% \mathrm{D} 9 \% 88 \% \mathrm{D} \% \% 86 \% \mathrm{D} 8 \% \mathrm{~A} 7-\% \mathrm{D} 8 \% \mathrm{~A} 7 \% \mathrm{D} 8 \% \mathrm{~B} 2-$

$\%$ D $\% \% 85 \%$ D8\%B1\%D8\%B2-0- $\%$ D $\% \% 87 \%$ D8\%B2\%D8\%A7\%D8\%B1-

$\% \mathrm{D} 9 \% 86 \% \mathrm{D} 9 \% 81 \% \mathrm{D} 8 \% \mathrm{~B} 1-\% \mathrm{D} 8 \% \mathrm{AC} \% \mathrm{D} 8 \% \mathrm{~A} 7 \% \mathrm{D} 9 \% 86 \% \mathrm{E} 2 \% 80 \% 8 \mathrm{C}-$

$\% \mathrm{D} 8 \% \mathrm{~A} 8 \% \mathrm{D} 8 \% \mathrm{~A} 7 \% \mathrm{D} 8 \% \mathrm{AE} \% \mathrm{D} 8 \% \mathrm{AA} \% \mathrm{D} 9 \% 86-55-$

$\% \mathrm{D} 8 \% \mathrm{~A} 8 \% \mathrm{DB} \% 8 \mathrm{C} \% \mathrm{D} 9 \% 85 \% \mathrm{D} 8 \% \mathrm{~A} 7 \% \mathrm{D} 8 \% \mathrm{~B} 1-$

$\% \mathrm{DA} \% \mathrm{~A} 9 \% \mathrm{D} 9 \% 88 \% \mathrm{D} \% \% 88 \% \mathrm{DB} \% 8 \mathrm{C} \% \mathrm{D} 8 \% \mathrm{AF})$.

Farzanegan, Mohammad. 2021. "Years of Life Lost to Revolution and War in Iran." CESIFO Working Papers.

Farzanegan, Mohammad Reza. 2020. "The Economic Cost of the Islamic Revolution and War for Iran: Synthetic Counterfactual Evidence.” Defence and Peace Economics 0(0):1-21. doi: 10.1080/10242694.2020.1825314.

Farzanegan, Mohammad Reza, and Pooya Alaedini, eds. 2018. Economic Welfare and Inequality in Iran: Developments since the Revolution. Softcover reprint of the original 1st ed. 2016 edition. London: Palgrave Macmillan.

Farzanegan, Mohammad Reza, Hassan F. Gholipour, and Jeremy Nguyen. 2016. "Housing Costs and Inequality in Post-Revolutionary Iran." Pp. 111-28 in Economic welfare and inequality in Iran, edited by M. R. Farzanegan and P. Alaedini. London: Springer.

Farzanegan, Mohammad Reza, and Bernd Hayo. 2019. "Sanctions and the Shadow Economy: Empirical Evidence from Iranian Provinces.” Applied Economics Letters 26(6):501-5. doi: 10.1080/13504851.2018.1486981.

Farzanegan, Mohammad Reza, Mohammad Mohammadi Khabbazan, and Hossein Sadeghi. 2016. "Effects of Oil Sanctions on Iran's Economy and Household Welfare: New Evidence from A CGE Model." Pp. 185-211 in Economic Welfare and Inequality in Iran: Developments since the Revolution, edited by M. R. Farzanegan and P. Alaedini. London: Palgrave Macmillan US. 
Fassihi, Farnaz. 2021. "Iran's Foreign Minister, in Leaked Tape, Says Revolutionary Guards Set Policies." The New York Times, April 26.

Harris, Kevan. 2017. A Social Revolution: Politics and the Welfare State in Iran. First edition. Oakland, California: University of California Press.

Hoodfar, H. 1994. "Devices and Desires: Population Policy and Gender Roles in the Islamic Republic.” Middle East Report (New York, N.Y.) 24(190):11-17.

Hoodfar, Homa. 2010. "Health as a Context for Social and Gender Activism: Female Volunteer Health Workers in Iran." Population and Development Review 36(3):487-510. doi: https://doi.org/10.1111/j.1728-4457.2010.00343.x.

Hoodfar, Homa, and Samad Assadpour. 2000. "The Politics of Population Policy in the Islamic Republic of Iran." Studies in Family Planning 31(1):19-34. doi: https://doi.org/10.1111/j.1728-4465.2000.00019.x.

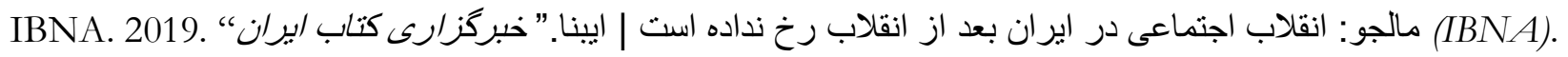

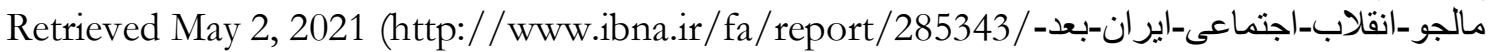
(ر)

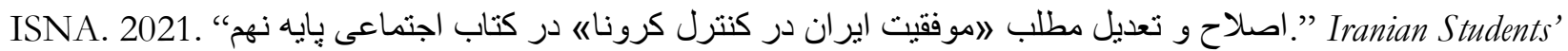
News Agency. Retrieved September 7, 2021

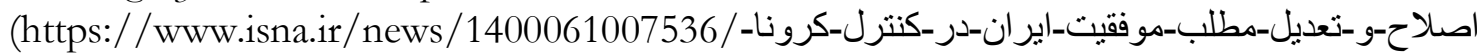
(در-كتاب-اجنماعى (د)

Kadivar, Mohammad Ali. 2013. "Alliances and Perception Profiles in the Iranian Reform Movement, 1997 to 2005.” American Sociological Review 78(6):1063-86.

Kadivar, Mohammad Ali, and Vahid Abedini. 2020. "Electoral Activism in Iran: A Mechanism for Political Change." Comparative Politics 52(3):493-514. doi: info:doi/10.5129/001041520X15718496292328.

Karshenas, Massoud. 2015. "Social Development, Income Distribution and Poverty under the Islamic Republic in a Comparative Perspective." Iran Nameh: A Quarterly of Iranian Studies 30(1):LXX-LXXXII.

Karshenas, Massoud, and Hamid Tabatabai. 2019. “Basic Income by Default: Lessons from Iran’s 'Cash Subsidy'Programme.” Pp. 339-55 in The Palgrave International Handbook of Basic Income, edited by M. Torry. Cham, Switzerland: Springer.

Keshavarzian, Arang. 2005. "Contestation without Democracy: Elite Fragmentation in Iran.” Pp. 63-90 in Authoritarianism in the Middle East: Regimes and Resistance, edited by M. P. Posusney and M. P. Angrist. Boulder, CO: Lynne Rienner.

Khomeini, Ruhollah. 1979a. “سخنرانى در بهشت زهرا (غير قانونى بودن مجلس و رزيم)." Emam.com. Retrieved June 9, 2021 (https://emam.com/posts/view/1248/\%D8\%B3\%D8\%AE $\%$ D $\% \% 86 \% D 8 \% B 1 \% D 8 \% A 7$ 
$\%$ D9\%86\%DB $\% 8 C-\%$ D8\%AF\%D8\%B1-\%D8\%A8\%D $\% \% 87 \%$ D8\%B4\%D8\%AA-

$\% \mathrm{D} 8 \% \mathrm{~B} 2 \% \mathrm{D} \% \% 87 \% \mathrm{D} 8 \% \mathrm{~B} 1 \% \mathrm{D} 8 \% \mathrm{~A} 7-\% 28 \% \mathrm{D} 8 \% \mathrm{BA} \% \mathrm{DB} \% 8 \mathrm{C} \% \mathrm{D} 8 \% \mathrm{~B} 1$ -

$\% \mathrm{D} 9 \% 82 \% \mathrm{D} 8 \% \mathrm{~A} 7 \% \mathrm{D} 9 \% 86 \% \mathrm{D} 9 \% 88 \% \mathrm{D} 9 \% 86 \% \mathrm{DB} \% 8 \mathrm{C}-$

$\%$ D8\%A8\%D \% \%88\% $\% \% A F \% D 9 \% 86-\% D 9 \% 85 \%$ D8\%AC $\%$ D9\%84\%D8\%B3-

$\% \mathrm{D} 9 \% 88-\% \mathrm{D} 8 \% \mathrm{~B} 1 \% \mathrm{DA} \% 98 \% \mathrm{DB} \% 8 \mathrm{C} \% \mathrm{D} 9 \% 85 \% 29)$.

Khomeini, Ruhollah. 1979b. صحيفه /مام خمبينى. Vol. 6. بايحاه كسترش آراء و انديشهای امام خمينى رحمة الله عليه.

Kjetil, Bjorvatn, Mohammad Reza Farzanegan, and Schneider Friedrich. 2013. "Resource Curse and Power Balance: Evidence from Iran.” Review of Middle East Economics and Finance 9(2):133-58.

Ladier-Fouladi, Marie. 1997. “The Fertility Transition in Iran.” Population an English Selection 9:191213.

Lob, Eric. 2018. "Regime Resilience, Social Welfare, and Economic Development in the Islamic Republic of Iran." Bustan: The Middle East Book Review 9(2):111-31. doi: 10.5325/bustan.9.2.0111.

Lob, Eric. 2020. Iran's Reconstruction Jihad: Rural Development and Regime Consolidation after 1979. Cambridge, UK: Cambridge University Press.

Mahoney, James. 1999. "Nominal, Ordinal, and Narrative Appraisal in Macrocausal Analysis." American Journal of Sociology 104(4):1154-96.

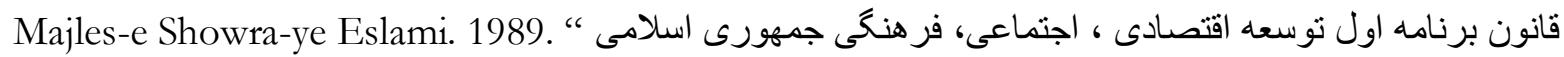
Retrieved June 8, 2021 (https://rc.majlis.ir/fa/law/show/91755).

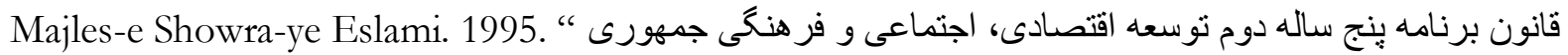

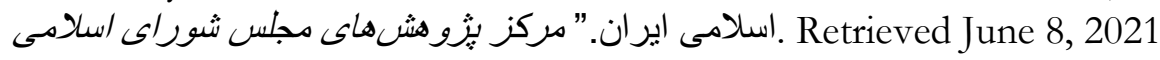
(https://rc.majlis.ir/fa/law/print_version/92488).

Majles-e Showra-ye Eslami. 2000، “قانون برنامه سوم توسعه اقتصادى، اجتماعى و فرهنكى جمهورى اسلامى 8 " Retrieved June 8, 2021 (https://rc.majlis.ir/fa/law/show/93301).

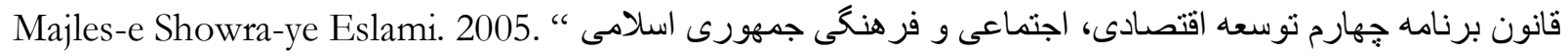
Retrieved June 8, 2021 (https://rc.majlis.ir/fa/law/show/94202).

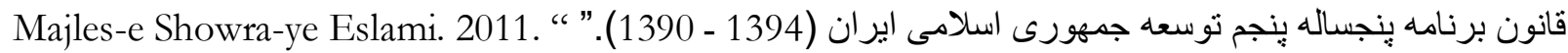
مetrieved June 9, 2021 (https://rc.majlis.ir/fa/law/show/790196).

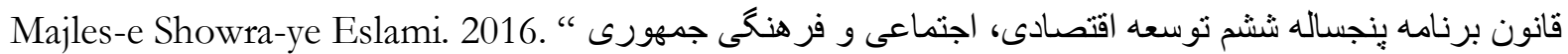
(اسلامى ايران ( . . Retrieved June 9, 2021 (https://rc.majlis.ir/fa/law/show/1014547). 
Marshall, James R. 1981. "Political Integration and the Effect of War on Suicide: United States, 1933-76." Social Forces 59(3):771-85.

Mashayekhi, Mehrdad. 2001. "The Revival of the Student Movement in Post-Revolutionary Iran." International Journal of Politics, Culture, and Society 15(2):283-313. doi: 10.1023/A:1012977219524.

Moghadam, Valentine, and Elham Gheytanchi. 2010. "Political Opportunities and Strategic Choices: Comparing Feminist Campaigns in Morocco and Iran." Mobilization: An International Quarterly 15(3):267-88.

Mohajer, Nasser. 2020. Voices of a Massacre: Untold Stories of Life and Death in Iran, 1988. Oneworld Publications.

Moslem, Mehdi. 2002. Factional Politics in Post-Khomeini Iran. 1 edition. Syracuse: Syracuse University Press.

Movahed, Masoud. 2020. "Industrializing an Oil-Based Economy: Evidence from Iran's Auto Industry." Journal of International Development 32(7):1148-70. doi:

https://doi.org/10.1002/jid.3499.

Piketty, Thomas. 2014. Capital in the Twenty-First Century. First Edition edition. Cambridge Massachusetts: Belknap Press.

Piketty, Thomas. 2020. Capital and Ideology. Cambridge, MA: Belknap Press: An Imprint of Harvard University Press.

Ramazani, Rouhollah K. 2013. Independence without Freedom: Iran's Foreign Policy. Charlottesville, VA: University of Virginia Press.

Rivetti, Paola. 2020. Political Participation in Iran from Khatami to the Green Movement. London: Palgrave Macmillan.

Roozarooz. 2021. “جكونه و اكسن بركت اول شد؟.. روزآروز. Retrieved September 7, 2021 (https://roozarooz.com/posts/590/\%DA\%86\%DA\%AF\%D9\%88\%D9\%86\%D9\%87$\% \mathrm{D} 9 \% 88 \% \mathrm{D} 8 \% \mathrm{~A} 7 \% \mathrm{DA} \% \mathrm{~A} 9 \% \mathrm{D} 8 \% \mathrm{~B} 3 \% \mathrm{D} 9 \% 86-$

$\%$ D8\%A8\%D8\%B1\%DA\%A9\%D8\%AA-\%D8\%A7\%D9\%88\%D \% \%84-

$\% \mathrm{D} 8 \% \mathrm{~B} 4 \% \mathrm{D} 8 \% \mathrm{AF})$.

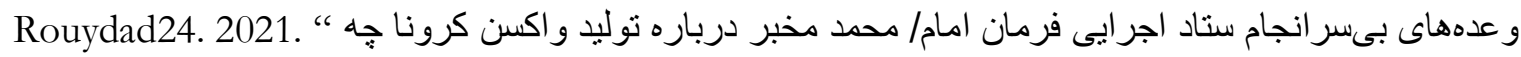

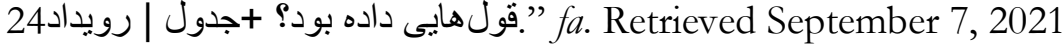

(http://www.rouydad24.ir/fa/news/275122).

Salehi Esfahani, Hadi, and M. Hashem Pesaran. 2009. "The Iranian Economy in the Twentieth Century: A Global Perspective.” Iranian Studies 42(2):177-211. doi: 10.1080/00210860902764896.

Salehi Isfahani, Djavad. 2017. "Poverty and Income Inequality in the Islamic Republic of Iran." Revue Internationale Des Études Du Développement (1):113-36. 
Salehi Isfahani, Djavad. 2019. "Iran’s Economy 40 Years after the Islamic Revolution.” Brookings. Retrieved April 23, 2021 (https://www.brookings.edu/blog/order-fromchaos/2019/03/14/irans-economy-40-years-after-the-islamic-revolution/).

Sen, Amartya. 1999. Development as Freedom. New York: Anchor books.

Sen, Amartya K. 2001. "What Is Development About?” Pp. 506-13 in Frontiers of Development Economics: The future in perspective, edited by G. M. Meier and J. E. Stiglitz. New York: Oxford University Press.

Shahrokni, Nazanin. 2019. Women in Place: The Politics of Gender Segregation in Iran. First edition. Oakland, CA: University of California Press.

Shahrokni, Nazanin. 2021. "Bursting at the Seams Economic Sanctions \& Transformation of the Domestic Sphere." Rethinking Iran at SAIS. Retrieved May 30, 2021 (https://www.rethinkingiran.com/iranundersanctions/nazanin-shahrokni).

Skocpol, Theda. 1979. States and Social Revolutions: A Comparative Analysis of France, Russia, and China. Cambridge, UK: Cambridge University Press.

Skocpol, Theda. 1982. "Rentier State and Shi'a Islam in the Iranian Revolution." Theory and Society 11(3):265-83. doi: 10.1007/BF00211656.

Skocpol, Theda. 1995. Protecting Soldiers and Mothers: The Political Origins of Social Policy in United States. Reprint edition. Harvard: Belknap Press.

Su, Dai, Yingchun Chen, Kevin He, Tao Zhang, Min Tan, Yunfan Zhang, and Xingyu Zhang. 2020. "Influence of Socio-Ecological Factors on COVID-19 Risk: A Cross-Sectional Study Based on 178 Countries/Regions Worldwide." MedRxiv 2020.04.23.20077545. doi: 10.1101/2020.04.23.20077545.

Tilly, Charles. 1992. Coercion, Capital and European States, A.D. 990 - 1992. Revised edition. Cambridge, MA: Wiley-Blackwell.

Tomlinson, Michael W. 2012. "War, Peace and Suicide: The Case of Northern Ireland." International Sociology 27(4):464-82.

Walt, Stephen M. 1997. Revolution and War. Ithaca, NY: Cornell University Press.

Yazdani, Farshid. 2020. "A Critical Review of a Social Revolution by Kevan Harris." The Political Economy Critique بقد اقتصاد سباسى. Retrieved April 23, 2021

(https:/ / pecritique.files.wordpress.com/2020/06/a-critical-review-of-a-social-revolution-bykevan-harris-.pdf). 